\section{2,000 US scientists boycott USSR}

IN what one participant called a "grass-roots" protest at the treatment of dissidents by the Soviet authorities, over 1,800 US scientists have signed a pledge to "withhold all personal cooperation with the Soviet Union" until Yuri Orlov and Anatoly Shcharansky, the two USSR scientists gaoled last summer, are released.

A further 600 US scientists have signed a separate pledge that they will not attend international conferences in the Soviet Union, will collaborate with and attend lectures by Soviet visitors only if they are invited, will oppose any enlargement of scientific and technical exchange programmes between the USSR and the US, and will "campaign against the transfer of sophisticated Western technology to the Soviet Union."

Signatures on the two petitions have been gathered by the Berkeley-based organisation Scientists for Orlov and Shcharansky, set up last summer when the trials of the two dissidents was taking place. SOS, as the organisation is known, says that its policy is to take concrete actions that deprive the USSR of some of the benefits of American science and technology, particularly in areas such as computing where the US has a considerable lead.

"The actions taken by SOS are a completely spontaneous response to Soviet policy, and are not connected to any position or policy of the US Government," Professor Kurt Gottfried, professor of physics at Cornell University, said last week.

"Our opposition to Soviet oppression is a limited response to Soviet actions, not a search for confrontation. Despite our commitment to human rights we view any linkage between human rights and the effort to achieve arms control as irresponsible," Professor Gottfried said, adding that SOS fully supported President Carter's efforts to negotiate a second Strategic Arms Limitation Treaty.

Gottfried was echoing Sakharov, who recently declared that human rights should not be made a sine qua non of the signing of the SALT agreement. While supporting Sakharov's opinion, John Macdonald, Q.C., Yurii Orlov's London-based "defence lawyer" nevertheless feels that the signing of SALT could lead to the release of political prisoners such as Orlov and Shcharanskii. It could well provide an opportunity for President Carter to press home the human rights issue-and for $\mathrm{Mr}$ Brezhnev to make a gesture which the Soviet Union could afford.

David Dickson and Vera Rich

\title{
Yugoslavia hits nuclear snag
}

Proposals to build Yugoslavia's second nuclear power station on the island of Vir (see map) are meeting with opposition from the island's inhabitants, as well as the municipal authorities and 'socio-political organisations' of the nearby resort town of Zadar on the central Adriatic coast.

The local inhabitants and authorities seem more interested in preserving their amenities as a tourist area than in the alleged advantages which the plant would bring to the area-which is notably short in energy.

The vigorous opposition to the nuclear power station comes only a few weeks after a series of major power cuts so severe that even long-standing atheists were observed buying votive candles from church-porch stalls. Yugoslavia's major power source is hydroelectricity, and the dry autumn and early winter led in December to cuts of up to eight hours a day.

It was just such a drought, six years ago, that led to a big drive for alternative sources of energy. Five foreign enterprises competed for the contract for the first Yugoslav power station. Westinghouse won, and work began at Krsko, near the Slovenia-Croatia border.

The target date for completion was January 1979, but construction was consistently behind schedule.

The delays, however, did not relegate

\section{UK must support talent, says minister}

Mrs Shirley Williams, UK secretary of State for Education and Science, is concerned that not enough young scientists are finding jobs-because most available posts are filled by people in their thirties and forties who are unlikely to move on. "If science in Britain isn't to sink gently into the second class", she told the Association of British Science Writers earlier this week, "then we will have to try to make room for each generation of outstanding talent."

Making more money available to the research councils should help solve the problem, she said, and that was one of the reasons behind the $4 \%$ increase in the science budget announced at the end of last year. Another reason for increasing the science vote was to take the pressure off the SRC, whose budget had been "blocked up by existing commitments" and to encourage the funding of interesting or important work by the other research councils.

A white paper is to be published this week, said Mrs. Williams, about the 'customer-contractor' principle whereby a portion of research council funds is administered by ministries, which

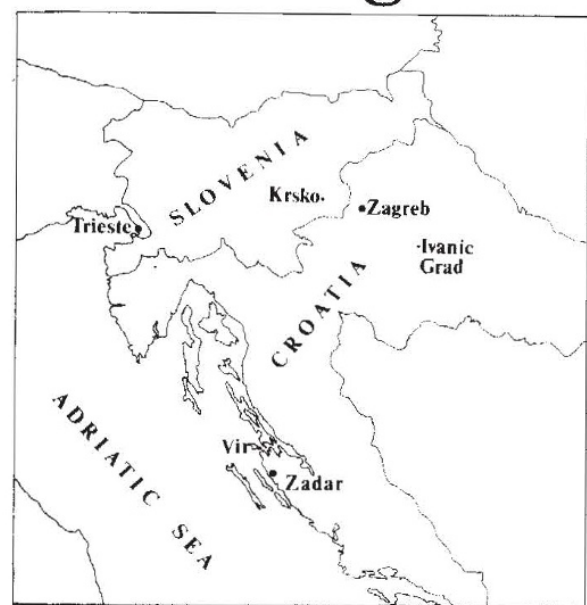

nuclear power in the minds of the Yugoslav planners. By April 1978, the power industry was talking in terms of 12 nuclear power stations with a total annual capacity of $66,000,000 \mathrm{MWh}$ by the end of the century.

So far, however, the Krsko station is still not operational and the siting of the second is in doubt. The final decision on the Vir site has not yet been reached-but local opposition suggests that a better choice might be Ivanicgrad, which not only has the necessary water resources, but is also a major industrial centre, where the local population may be less likely to raise environmental issues.

Vera Rich commission research relevant to their needs. For the system to work, says Mrs Williams, "commissioned research has to be handled on a basis of stability and on a relatively long lead time". Problems occur if the level of research commissioned by a ministry is suddenly changed.

There is also a limit to that level and, according to Mrs Williams, the Agricultural Research Council's budget has already reached it. The increase in the science vote, however, should relieve some of the research council's dependence on commissioned research.

Mrs Williams is also concerned that the UK does not make the most of its innovative ideas. "It is sad", she says, "that one so often sees the brilliant idea worked on in a university laboratory being patented in another country and then sold back to us." She would like to see small companies encouraged to take up new jdeas and the establishment of a "small enterprise board" which would assume for enterprise a similar role to that taken by the National Research Development Corporation for technology.

Judy Redfearn 